\title{
Muhammad Asad between Religion and Politics*
}

\author{
Talal Asad**
}

In April 2011 an international symposium was held in Riyadh, under the auspices of the King Faisal Center for Research and Islamic Studies as well as the Austrian Embassy to Saudi Arabia, on the life and work of my father. The conference as a whole was entitled "Muhammad Asad - A Life for Dialogue," but I was asked by the organizers to write something on "Muhammad Asad Between Religion and Politics." Unfortunately I was unable to attend the symposium so I sent in my contribution to be read out by someone else at the meeting. What follows is an edited and elaborated version of what I sent.

I should begin, however, by correcting a view that has become common among people interested in my father's life and work, that his conversion can be seen as the building of a bridge between Islam and the West. He has even been described by some as a European intellectual who came to Islam with the aim of liberalizing it. Nothing could be further from the truth. When he embraced Islam (aslama, "submitted," is the Arabic term) he entered a rich and complex religious tradition that had evolved in diverse ways - mutually compatible as well as in conflict with one another - for over a millennium-and-a-half. Thus in his own life's work he sought to use the methodology of the medieval Spanish theologian Abu Muhammad Ibn Hazm, he drew often and copiously on the interpretations of the nineteenth-century Egyptian reformer Muhammad Abduh, and again, despite strong disagreement on various points of substance with the fourteenth-century Syrian theologian Taqi al-Din Ahmad Ibn Taymiyya, he attempted, like the latter, to integrate reason ('aql), tradition (naql), and free-will (irada), to form a coherent and distinctive vision of Islam. His view of Sufism, incidentally, was also influenced by Ibn Taymiyya, for whom it was the excess of Sufis rather than Sufism as such

* This paper presented at the symposium antitled "Dr. Momammad Asad - A Life for Dialogue" in April 11, 2011 in Riyad at the King Faisal Center for Research and Islamic Studies.

** Prof., City University of New York Department of Anthropology,

Correspence: talalasad@earthlink.net, The CUNY Graduate Center 365 Fifth Avenue, New York, USA

AtıfO: Asad, T. (2011). Muhammad Asad between religion and politics. Insan ve Toplum, 1 (2), 155-165. 
that was the object of reproach. In fact most of what my father published in the early years of his life (Islam at the Crossroads, the translation of Sahih al-Bukhari, the periodical Arafat, etc.) was addressed not to Westerners but to fellow-Muslims. I would say, therefore, that he was concerned less with building bridges and more with immersing himself critically in the tradition of Islam that became his tradition, and with encouraging members of his community (Muslims) to adopt an approach that he considered to be its essence. His autobiography was the first publication that was addressed to non-Muslims (as well as to Muslims, of course), a work in which he attempted to lay out to a popular audience not only how he became a Muslim but also what he thought was wonderful about Islam.

My father was not a politician but a religious thinker for whom the Qur'an and Sunnah together formed what he called "the most perfect plan for human living." It was in this connection that he wrote on the idea of an Islamic state, and even prepared suggestions for an Islamic Constitution in Pakistan. These suggestions were elaborated in his well-known book, Principles of State and Government in Islam. But his interest in that subject declined in later years when he became preoccupied with his translation of the Qur'an. Like most intellectuals who have lived a long life (he died at the age of 92) his views evolved and developed through reflection and changing circumstances. I am not able to trace this development here, but I will nevertheless try, by thinking about what he said and wrote two decades after his death, to interpret and reconstruct what I believe was his basic vision of Islam. In doing so I will sometimes disagree with what he wrote and sometimes try to make explicit what I see as valuable but implicit in his views.

The first and most important idea in my father's vision has to do with his conviction that access to Islam is based on reason, and that therefore argument is necessary to becoming and being a Muslim. When I was a boy he used to tell me that one must try to persuade other Muslims and non-believers not by force but by reason: This is what the Qur'an means by saying lä ikräha fi-ddin. In the Qur'an, he pointed out, God always addresses human beings by appeal to reason. If you read it carefully, you will realize that the Qur'an is continually engaged in argument by means of provocative questions because argument is what it expects its listeners to value. Sometimes it addresses all human beings (ayyuhan-nas), and sometimes it addresses Muslim believers in particular (ayyuhal-mu'minin) in an argumentative mode, attempting in its appeal to persuade its listeners to awake to another life. The arguments do not aim to provide irrefutable proof, they try to induce the listener to open herself up to an extraordinary possibility. The Qur'anic references to suffering in the life to come can mean nothing to a non-believer; they are offered by the Qur'an as ways of sharpening the awareness of someone who already believes. And the Qur'an is a guide (huda) to those among mankind who want to be guided aright. So when persuasion fails, he insisted that Muslims 
must live in mutual acceptance with the followers of all religions: lakum dinakum wa liy ad-din.

In this context I recall my father often reciting the following verses: Inn alladhina āmanu walladhīna hādu wa-nnasāra wa-ssābi'îna man āmana billāhi wa-l-yaumil-äkhiri wa 'amila sālihan falahum ajruhum 'inda rabbihim wa lā khawfun 'alayhim wa lā hum yahzanūn. [Sūrat al-baqarah, 62]. There was nothing, he would point out, quite like these verses either in the Hebrew Bible or in the Gospels. And the verses reinforced the fact that, according to Islamic teaching, followers of Judaism and Christianity ( $a$ hl al-kitab) belong to the very tradition that culminates in Islam: They were earlier revelations that had become distorted over time but were nevertheless to be recognized as having truth in them. They might be doctrinally mistaken but it followed from the fact of a common tradition that they were to be respected. Unlike the historic Christian view, the continued presence of believers in an earlier monotheistic religion is not regarded by Islam as a scandal but as an indication of how easy it is to remain stubbornly attached to a mistaken point of view. In the "real Islamic tradition," he would say, there is no simple distinction between friend and enemy, no binary divide that categorizes people of the world into good and evil. To my father this meant therefore that the tradition of Islam not only urged Muslims to tolerate the followers of all other religions, it encouraged them to consider all as deserving of equal respect. And respect meant being able to listen to what they had to say about their deepest hopes and commitments. In that sense respecting someone was a way of including him/her within one's circle of friends - even if that was limited to the followers of what we now call monotheistic (or Abrahamic) religions. My father acknowledged that there were other verses in the Qur'an that appeared to exclude Jews or Christians, but he held that these were responses to specific historical circumstances in the Prophet's life and they referred to particular groups whose behavior in particular situations indicated the difficulties of an alliance between them and the nascent Muslim community. These verses were not, he insisted, doctrinal statements about the place of entire traditions within the Islamic scheme of things.

Incidentally my father often complained that Westerners viewed Islam as an aggressive intolerant religion that carried out its conversions in later centuries by force. And of course it is true that the conversion of non-believers to Islam in the early centuries was not the outcome of force except in marginal cases, but by and large the theme of non-Muslim conversions to Islam, and their relationship to power, is still very much under-explored, and too often described in crude terms (fear, material interest, the recognition of manifest truth). The assumption that religious conversion marks an absolute exit from one category and entry into another is surely too simple - unless it is legal status that is at issue. At any rate, 
the false claim that conversion to Islam was essentially achieved by force remains very common in the West. A recent example of this thesis is the extraordinary lecture given a few years ago in Regensburg by Pope Benedict in which he claimed that whereas Reason was central in Christian history it was all but absent in the history of Islam, which was why Islam typically relied on force and violence.

For my father, however, "reason" was central not only to the way Muslims ought to address non-Muslims and the way they should live as individual believers. Reasoned argument was central to the way Muslims should treat disagreements among themselves - whether in public matters or in private life. In his view, deep disagreements should never lead to the denunciation of other Muslims as unbelievers (takfir), they should produce debate in which each side respects the other even when agreement cannot be reached. Hence he quoted the Prophet's saying: ikhtiläf 'ulamā ummati rahma. He himself disagreed strongly with many other Muslims about the correct interpretation of Islamic doctrine and practice. But he despised religious bigotry (ta'assub, tashaddud) and religious excess (ghulüww), and he hated cruelty perpetrated in the name of religious conviction - whether by mobs, or by individuals, or by the state. One was a Muslim if one declared oneself a Muslim; the sincerity of that declaration was a matter between him/her and God only.

My father considered religion in general (and as a Muslim, the religion of Islam in particular) to be essential for distinguishing between what was morally right or wrong, and it was in this that he sought the justification for an Islamic state. He once summed this up in writing as follows: "No nation or community can know happiness unless and until it is truly united from within; and no nation or community can be truly united from within unless it achieves a large degree of unanimity as to what is right and what is wrong in the affairs of men; and no such unanimity is possible unless the nation or community agrees on a moral obligation arising from a permanent, absolute moral law. Obviously, it is religion alone that can provide such a law and, with it, the basis for an agreement, within any one group, on a moral obligation binding on all members of that group." (Principles of State and Government in Islam, 1961, p. 6, italics in original.) It is interesting that this argument for the necessity of an Islamic state rests not on what he often called "blind obedience to the past," but on "reason." However, if reasoning is the way the Islamic state is justified, then reasoning may also question its necessity, as I will try to do in what follows.

For my father ethics and law are here virtually identical - especially for Muslims who are required to be obedient to the will of God. My father believed that a state had to be built on religious foundations because only a state could give divine law the force it needed to be law - and God's law (God's will), was the source of all true morality and happiness. But here is my worrying question: Is it possible 
for non-Muslims to live ethically within an Islamic state? Is there a limit to their trustworthiness if they are not subjected to the ethical force of state law?

Like many advocates of an Islamic state, my father maintained that although non-Muslims were entitled to complete protection they could not occupy leading positions in an Islamic state. He thought that this was not a case of unfair treatment but, on the contrary, a recognition of the fact that non-Muslims should not be required to be "totally loyal" (as he put it) to the state that embodied an ideology quite different from their own. The state, in other words, was entitled to demand total loyalty from those in leading positions, and the latter were expected to secure the obedience of all who were subjected to national law. Since non-Muslims were unable to fulfill this double function in an Islamic state, there had to be a recognition of this fact. What could be more reasonable?

I want to begin my response by stressing that the state's demand for absolute loyalty and unity from all its subjects is entirely modern. Political unity of all citizens and their unconditional loyalty to the state are principles of the nation state invoked in defense against enemies - hostile states as well as traitors - principles that pre-modern states could not demand and did not require. For pre-modern princes it was the loyalty of nobles, generals, and governors that mattered not that of ordinary subjects. Precisely because the modern state's fundamental rationale is fear of external and internal enemies, it uses its power to demand unity. Where commitment to this end is not forthcoming on the part of individual citizens, the state will secure obedience by force, regardless of their doubts and disagreements. In such a state other political societies become its actual or potential enemies, and like any state that considers its very survival to be paramount, it will use every means available to defend itself.

Not everything that has emerged in the modern world is wonderful.

The modern liberal state is a structure that is both the means of common benefits as well as a source of possible cruelty and oppression. Rulers and ruled stand apart from the state; the former come and go but the state is immortal. The government takes care of the state's unity and represents the citizens whose state it is. In addressing its citizens the government does not seek to persuade, it uses the law to command in the "interest of the nation;" and it has the means to punish those who disobey. The law can, of course, be interpreted in almost endless ways, but it is the judicial arm of the state in which the authoritative decision is finally made as to which interpretation prevails. And it is precisely the pronouncement of a particular interpretation as the Law that gives some forms of violence their legitimacy. The state's monopoly of violence, and the centralized bureaucracy that is its primary instrument in maintaining order, gives it power that is far greater than anything citizens alone can muster. It is true that the liberal, secular 
state protects the right to association and dissident speech, but no state (through its government) allows what it calls seditious libel because that is a threat to its sacred existence.

It is not surprising that some Muslims consider that total loyalty to the state (and the modern state does demand unquestioning loyalty) contradicts the absolute loyalty they are expected to give to the one and only God. Like most Muslims, my father considered the identification of God with his creation to be heretical. And the modern state is a creation of his creatures. Loyalty to God can't therefore be preceded by absolute loyalty to a creation of his creatures. It is therefore not entirely clear to me why my father should have endorsed the right of the Islamic state to absolute loyalty, especially since the declaration of faith (shahada) itself specifies absolute loyalty only to God and his Prophet and makes no mention of obedience to earthly rulers or to an earthly organization.

Unlike Carl Schmitt's famous theory of "sovereignty" that expounds a political theology, in the salafi tradition the state cannot be legitimized through a secularized concept of divinity, on the analogy of what Schmitt called the sovereign's ability to determine the exception in law and God's ability to intervene in the order of nature by miracles. In that Islamic tradition, God cannot be conceived of as a heavenly Patriarch (as in the early modern European tradition of the divine right of kings), or as the founder of a heavenly Covenant (as in early modern political discourses on social contract). A corollary of the absence of a theory of "sovereignty" in this tradition is that the modern state has no claim on the absolute loyalty of its subjects. Many advocates of an Islamic state today assert that God has absolute sovereignty over it. But since Qur'anic doctrine insists that everything in the universe is subject to divine sovereignty, how does the state, as a social construct, get its special right to demand absolute loyalty from its subjects? It is precisely because no state can claim divine sovereignty that no spokesperson of an Islamic state can do so. The state may be necessary in our contemporary world for a number of desired functions that only it can perform, and to the extent that it does this in ways considered just and efficient, support from its subjects - as well as from foreigners who live in or visit its territory - will be forthcoming. But the state has no theological title to sovereignty in Islam because unlike Schmitt's argument that invokes a Christian history, the Islamic state cannot speak as God would speak. It is a creation, not the Creator.

It has been suggested that non-Muslims cannot provide absolute loyalty to the Islamic state in which they happen to live, and I have argued not that they can provide that loyalty but that the very idea of absolute loyalty in an Islamic state is suspect. But what else can non-Muslims not do in an Islamic state? My father insisted that all citizens of an Islamic state, including non-Muslims, have the right 
to public dissent, the right to criticize their government publicly. But to what extent can non-Muslim citizens in an Islamic state criticize a government that is strictly speaking not their government. This is not simply a question about fear but also about their involvement. Part of the answer is that the Islamic state has an obligation to protect non-Muslims and allow them total freedom in matters of speech and "belief." But the obligation to protect everyone equally does not entail their right to participate as equals in public life. Thus when we say that adults have the obligation to protect children this doesn't mean that children have the right to participate equally in adult life. Should non-Muslims in an Islamic state be regarded as children to be protected? Or should they be encouraged to leave their homeland for a state that does not have a Muslim majority? The point is that if the state is not "theirs," non-Muslim citizens cannot really be represented by the Islamic state in which they live - just as the Palestinian citizens of Israel (whether Muslim or Christian) cannot be represented by the Jewish state.

So I respectfully disagree with my father on this matter, and to support my disagreement I invoke the Prophet's saying: ikhtiläf 'ulamā ummati rahma, since we are both learned in the Islamic tradition, even if it is true that he was by far the greater scholar.

I think that one can, nevertheless, detect something else in my father's argument for an Islamic state that I suggest is worth taking seriously: the place of religion and morality in political life. This requires us first of all to make a distinction between state and politics, the former having to do with the exercise of power and the demand for obedience (whence the law of treason), and hence essentially with fear - fear of external and internal violence. Legal punishment and war are central functions of the sovereign state. This conception of the state is, famously, the one put forward by Thomas Hobbes, and it serves as a beginning of the Western tradition of theorizing about the modern state. Politics, on the other hand, involves debate, struggle, and the claim to equality - because someone who disputes my view claims that in this respect he or she is equal to me. Politics may be, but need not be, focused on state power. Only sovereignty makes the demand that the state be the center and only meaning of politics.

Must only power and material interest prevail, or can a place be found for morality and religion in public life? Even the famous doctrine of 'amr bil-ma'ruf does not presuppose a state, and the doctrine la ikrāha fi-ddin cannot mean that the state has the right to impose by law any belief and behavior on Muslims. Of course in the history of Islam the prince has often justified his rule by his ability to defend Islam at home and abroad - but not everything that has been accepted in history is right because it is historical. The fact that in Muslim history 'amr bil-ma'ruf has often been assumed to be a duty of the state does not by itself mean that Muslims 
must accept the same arrangement today if they are to remain genuine Muslims. Ethics may be part of politics without being made into a function of the state.

In recent versions of liberal political theory public and private spheres are sharply distinguished (even when in fact they are not), just as law is clearly differentiated from morality (even though they are interconnected in real life). Politics is, accordingly, seen as subject to a morally neutral procedure regulated and shaped by a secular state, and religion as one of the domains in which absolute commitments and values are privately located. Moral and religious values are to be excluded from the state on the grounds that conflicts between differences they give rise to can never be rationally resolved and can lead to uncontrollable violence. Liberal theory therefore assigns moral and religious values to the private domain where autonomous subjects are expected to maintain their religious convictions and make their moral decisions. But I would join those critics who challenge the assumption that a secular state ensures peace and the entry of religion into politics ensures war or civil disorder.

For those who are reluctant to allow the state to authorize the morality of a national population, but who nevertheless disagree with the liberal principle that prohibits the entry of morality and religion into national politics, there is the question: Can ethics and religion be brought into public life without their being made subject to sovereignty - and therefore either co-opted by or disruptive of the state? This question was also implicit, I suggest, in my father's concerns. His preoccupation with ethics is at the bottom of his thinking about the Islamic state. But in my view what he omitted to discuss was the difference between politics and the state.

Politics need not be concerned with the determination of "national interests;" it can be concerned with securing spaces that are external to the authority of the sovereign state and guided by principled commitments that transcend "the nation." In these spaces subjects do not just escape the state; when necessary they confront and even disobey it on religious or moral principle. This principle can reject the state's insistence on monopolizing politics.

Religion is and has been historically an important source of principled behavior. It can therefore be suggested that for Muslims the possibilities of political Islam may lie not in its aspiration to acquire state power and to apply state law but in the practice of public argument and persuasion itself - in a struggle guided by deep commitments that are both narrower and wider than the limits of the nation state. Politics in this sense is not a duel between pre-established positions: it is about values in the process of being discovered (or rediscovered) and formed. It presupposes openness and a readiness to take risks that the modern state cannot tolerate. 
I end with a substantive point about my father's moral vision and its connections to state and politics that seems to me especially important.

More than once he recited Surat at-takāthur to me with great feeling: "alhäkumut-takäthur hatta zurtum al-maqäbir....." These verses, he would say, condemn the unending consumerism and greed in which humans (especially in our time) are entrapped: The verses that refer to 'ilm al-yagin and that speak of latarawunna al-jahim, alerts us to the hell in which we actually live in this world, not merely to punishment in the life to come. My father read these verses as arguing that if we could see this truth with clarity we would realize the hellish aspect of our collective life, the damage we do to ourselves and to others. This was a central moral concern for him, and it points to where an Islamic politics might begin: Muslims are expected to believe that greed as a collective way of life (the insatiable desire for more) and exhibitionism as an individual style (in which theatrical presentations of the self and consumer choices are confused with moral autonomy) have together seduced people away from what he called "God-consciousness" - and therefore from an awareness of the objective consequences of the way we live (militarization of societies, growing disparity between rich and poor, unceasing destruction of the natural environment, accumulating climatic and nuclear disasters).

Yet what is not always appreciated is that a central precondition of the way we live now is dependent on a particular kind of state, not only one demanding absolute loyalty, but also regulating and promoting consumerism and individualism. In other words, the secular liberal state encourages a paradoxical value according to which "freedom" in the form of the market, and of laws to protect and extend it, is entirely compatible with the increasingly intrusive security measures by which the state limits "freedom" in order to defend it. To the extent that this state serves a neo-liberal economy (the reckless extension of market principles throughout society, the privatization of property, the maldistribution of benefits, and the unrestrained pursuit of profit in an increasingly unstable world) an Islamic politics might find spaces outside it - even against it - and not aim to replace it by a particular "religious" ideology. The forces of global capitalism have a powerful effect on the choices available to a so-called "sovereign" state, regardless of whether it is Islamic or secular. This requires Islamic politics to make alliances with appropriate non-Islamic movements and traditions both within the national territory of the state and beyond.

The struggle for human justice and public virtue, is opposed to an overriding interest in material accumulation, in securing what one enjoys in fear of others who might covet what one owns. It is peaceful political struggle in the cause of what is morally right that transcends the fear of death. This kind of politics does not accept the liberal state's claim to secular neutrality. Politics in this sense arises 
out of a desire to extend and defend the fundamental value of a democratic ethos rather than the sovereignty and power of the liberal democratic state.

What is the difference between what is sometimes called a "democratic ethos" and "real democracy" about which one hears so much nowadays? Although this question can't be answered adequately here, a few points may help to indicate the difference: When we speak of a democratic ethos we often think of the desire for mutual care and respect, the concern to understand others - to listen to others and not merely to tell them what they must do, and the readiness to suffer for the sake of others. In the democratic ethos the individual is imbued with a sense of his finitude, of vulnerability and decay. The spectacle of pain and disintegration in others invites compassion. And yet it takes one's own pain not simply as a sign of being unwell but also as a way of living positively without glorifying suffering. On the other hand, when we refer to a liberal democratic state, we think of it as the guardian of rights and the focus of collective identity. We are aware of the power of a unified body, of the legal freedoms of all citizens, of the state's paramount concern with security. We recognize that the state is a structure separate from rulers and ruled, with the right to punish violators of national laws, and to wage war in defense of its national interests. In a representative democracy the individual is the object of protection from the violence of others and of nature, and the monopoly of violence by the sovereign is a means to that end. The nation state responds to the fear of all citizens by offering them security, and at the same time a kind of immortality through self-sacrifice for "the higher good of the state". Here selfsacrifice is a demand of the state presenting itself as the supreme representative of all citizens, not a moral act performed by the individual for the sake of others. I repeat: of course this is not the only thing the modern state does; it also enables law and order and provides welfare (often more of the former than the latter). But it is only unarmed struggle as a moral/religious act (jihad), a struggle without fear of death but not a struggle for death, that can sustain a concern for the enhancement of common life, and that can confront contemporary global disasters.

Politics in this sense cannot be seen as a matter of procedure, of aiming at "justice as fairness," as the famous liberal theorist John Rawls put it. In my view, the specific ends that an Islamic politics might seek to attain, depends on inviting interlocutors (trying to persuade them) to alter their individual and collective ways of life in a morally better direction. Political persuasion presupposes particular sensibilities in listeners and appeals to the manifest character of the person who seeks to persuade, as well as the substance of what is actually said, done, and demonstrated. The sensibilities and qualities of character are together what an Islamic politics might aim to cultivate in its own distinctive way. This is not "politics" in a narrow, state-defined sense; it is not concerned simply and directly with 
trying to formulate national policies that the state will then impose as laws on the national population. It is not confined to formal verbal debate. This politics includes the building of civil relationships and friendships with non-Muslims as well as Muslims, it includes the readiness to argue but also the ability to listen and to change one's mind as a consequence. This politics is directed at nominal Muslims as well as nominal non-Muslims, and it invites them both to transform themselves from one position (or mode of living) to another.

The first thing that ought to strike one is how different this notion of politics is from Carl Schmitt's influential definition in terms of the "friend/enemy" binary, a definition firmly linked to the concept of the sovereign state. It seems to me evident that the notion of an Islamic politics would draw one away from the project of an Islamic state that is no different in essence from any modern state. I believe that this is also the view that is implicit in my father's life and writing. For that reason it constitutes an important part of his legacy. Certainly it is more important than the idea of "a dialogue between Islam and the West" that has now become so fashionable. The so-called "dialogue of civilizations" seems to be based on a double premise: (a) that Muslims should try to reassure Europeans and North Americans that Islam is not a source of violence, and at the same time, (b) that Westerners should help to reform Islam. This is a very condescending notion. Of course Muslims should open their minds to other societies and traditions, and learn from them critically; just as one hopes Westerners will to learn from Islamic thought and experience critically (even if most of them do not want to do so). As for reform, it should be borne in mind that Islam's history of reform is virtually as old as the religion itself. Of course Islamic reform today will need to be original. But in my view the effectiveness of that reform is partly dependent on simultaneous reform in the West. We do, after all, live in an interconnected world. 